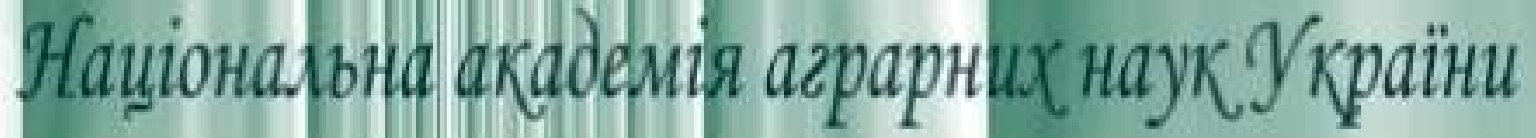

_нститут тваринництва

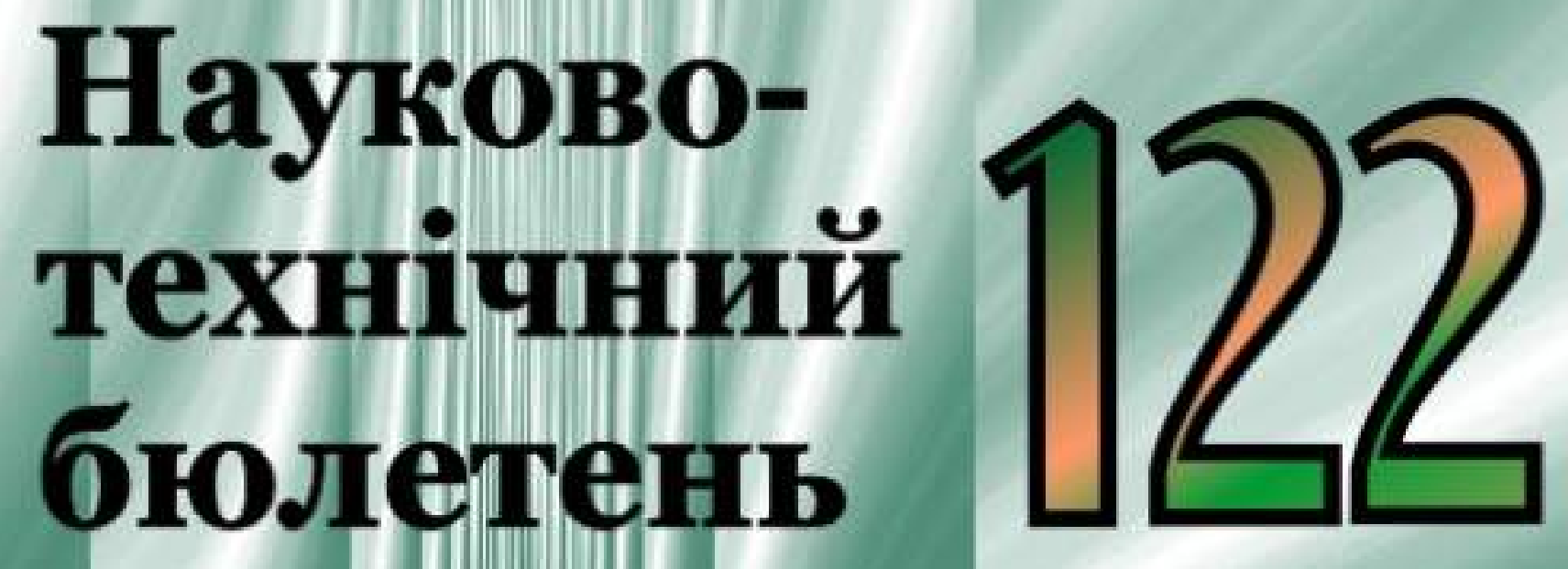

ІНСТИТУТУ ТВАРИННИЦТВА НААН

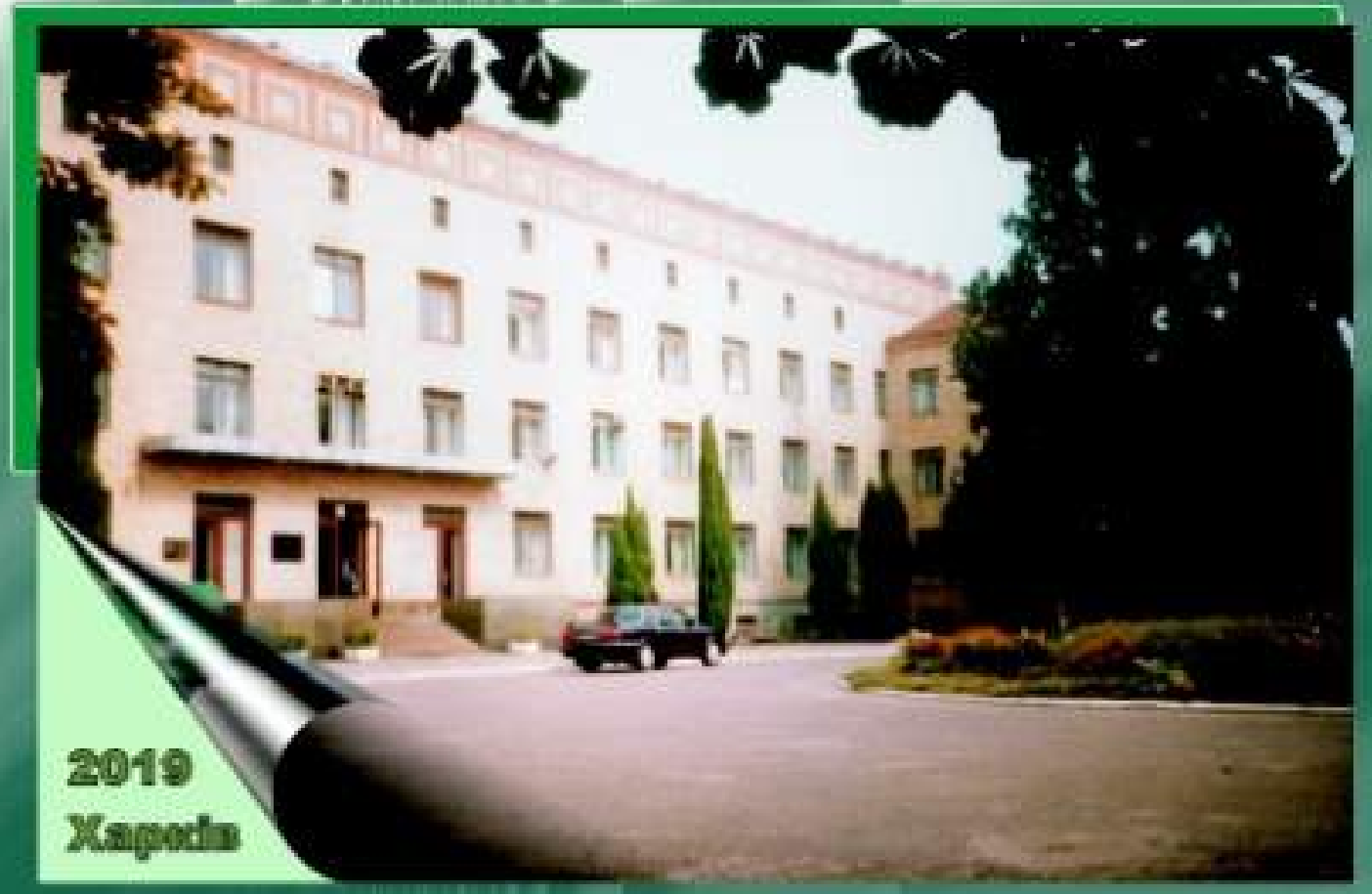


НАЦІОНАЛЬНА АКАДЕМІЯ АГРАРНИХ НАУК УКРАЇНИ ІНСТИТУТ ТВАРИННИЦТВА

\section{Науково-технічний бюлетень}

Інституту тваринництва НААН № 122

Харків-2019 


\section{УДК 636:001(045) \\ DOI 10.32900/2312-8402-2019-122}

Науково-технічний бюлетень Інституту тваринництва НААН № 122 / Нац. акад. аграр. наук України, Інститут тваринництва. Харків, 2019, 263 с.

У виданні висвітлено результати науково-дослідних робіт з різних напрямів аграрного виробництва. Номер присвячено 90-річчю від дня заснування Інституту тваринництва НААН.

Свідоцтво про державну реєстрацію: серія КВ № 21410-11210ПР від 25.06.2015 р.

\section{Редакційна колегія:}

Головний редактор - Руденко Є. В., Інститут тваринництва НААН, директор, доктор вет. наук, професор, член-кореспондент НААН

Заступник головного редактора - Помітун І. А., Інститут тваринництва НААН, заступник директора $з$ наукової роботи, доктор с.-г. наук, професор

Відповідальний секретар редколегії - Кунець В. В., Інститут тваринництва НААН, старший науковий співробітник, канд. іст. наук, старший науковий співробітник

\section{Члени редакційної колегії:}

Василевський М. В. Інститут тваринництва НААН, завідувач лабораторії, канд. біол. наук, старший науковий співробітник

Катеринич О. О., Державна дослідна станція птахівництва НААН, директор, доктор с.-г. наук, старший науковий співробітник

Корх І. В., Інститут тваринництва НААН, провідний науковий співробітник, канд. с.-г. наук, старший науковий співробітник

Кулібаба Р. О., Інститут тваринництва НААН, завідувач лабораторії, доктор с.-г. наук, старший науковий співробітник

Піскун В. І., Інститут тваринництва НААН, завідувач лабораторії, доктор с.-г. наук, старший науковий співробітник

Подобєд Л. І., Інститут тваринництва НААН, завідувач відділу, доктор с.-г. наук, професор

Россоха В. І., Інститут тваринництва НААН, завідувач лабораторії, канд. с.-г. наук, старший науковий співробітник

Сушко О. Б., Інститут тваринництва НААН, завідувач відділу, канд. с.-г. наук, старший науковий співробітник

Ткачова І. В, Інститут тваринництва НААН, провідний науковий співробітник, доктор с.-г. наук, старший науковий співробітник

Трішин О. К., Інститут тваринництва НААН, головний науковий співробітник, доктор с.-г. наук, професор, академік НААН, заслужений працівник сільського господарства України

Церенюк О. М., Інститут тваринництва НААН, завідувач відділу, доктор. с.-г. наук, доцент

Шкавро Н. М., Інститут тваринництва НААН, вчений секретар, канд. с.-г. наук, старший науковий співробітник

Шейко І. П., Науково-практичний центр НАН Білорусі з тваринництва, перший заст. генерального директора, доктор с.-г. наук, професор, академік НАН Білорусі, Заслужений діяч наук Республіки Білорусь (республіка Білорусь)

Eugeniusz Herbut, Instytut Zootechniki PIB, Dzial Technologii, Ekologii i Ekonomiki Produkcji Zwierzqcej, Doctor habilitowany, Profesor (республіка Польща)

Waldemar Korol, Instytut Zootechniki PIB, Kierownik Krajowego Laboratorium Pasz w Lublinie, Doctor habilitowany (республіка Польща)

Рекомендовано до друку за рішенням Вченої ради Інституту тваринництва НААН (протокол № 14 від 12.11.2019 р.).

Збірник включено до нового переліку наукових фахових видань Украӥни, міжнародних наукометричних баз даних Російський індекс наукового цитування - (РІНЦ) (ліцензійна угода № 649-10/2013 від 23 жовтня 2013 р.) та Google Scholar.

Електронна версія розміщується на порталі НБУВ (Національної бібліотеки ім. В. І. Вернадського) та на wеb-сторінияі видання на wеb-сайті засновника http://animal.kharkov.ua/index.php/cains-publication/ntb

Індивідуальний префікс установи в системі Crossref 10.32900. Науковому контенту журналу присвоєно міжнародний циифровий індефікатор DOI (Digital Object Indentifier).

ISSN 2312-8402

(C) Інститут тваринництва НААН, 2019 


\section{UDK 636:001(045) \\ DOI 10.32900/2312-8402-2019-122}

The Scientific and Technical Bulletin of the Institute of Animal Science NAAS of Ukraine № 122. Kharkiv, 2019, 263 p.

The Bulletin highlights the results of research work in different areas of agricultural production. The issue is dedicated to the 90th anniversary of the founding of the Institute of Animal Science of the NAAS.

Certificate of state registration: series КВ № 21410-11210ПР dated 25.06.2015

Editorial board:

Editor-in-Chief - Rudenko E. V., Institute of Animal Science of NAAS, Director, Doctor of Veterinary Medicine. Sci., Professor, Corresponding Member of NAAS

Deputy Editor-in-Chief - Pomitun I. A., Institute of Animal Science of NAAS, Deputy Director for Scientific Work, Doctor of Agricultural Sci., Professor

Editor-in-Chief of the Editorial Board - Kunets V. V., Institute of Animal Science of NAAS, Senior Researcher, Candidate of Hist. Sci., Senior Researcher

\section{Members of the Editorial Board:}

Vasilevsky M. V., Institute of Animal Science of the NAAS, Head of Laboratory, Candidate of Biological Sci., Senior Researcher

Katerynych O. O., NAAS State Poultry Research Station, Director, Doctor of Agricultural Sci., Senior Researcher

Korh I. V., Institute of Animal Science of NAAS, Leading Researcher, Candidate of Agricultural Sci., Senior Researcher

Kulibaba R. O., Institute of Animal Science of the NAAS, Head of Laboratory, Doctor of Agricultural Sci., Senior Researcher

Piskun V. I., Institute of Animal Science of the NAAS, Head of Laboratory, Doctor of Agricultural Sci., Senior Researcher

Podobed L. I., Institute of Animal Science of the NAAS, Head of Department, Doctor of Agricultural Sci., Professor

Rossokha V. I., Institute of Animal Science of the NAAS, Head of Laboratory, Candidate of Agricultural Sci., Senior Researcher

Sushko A. B., Institute of Animal Science of the NAAS, Head of Department, Candidate of Agricultural Sci., Senior Researcher

Tkachova I. V., Institute of Animal Science of the NAAS, Leading Researcher, Doctor of Agricultural Sci., Senior Researcher

Trishin O. K., Institute of Animal Science of NAAS, Chief Research Fellow, Doctor of Agricultural Sci, Professor, Academician of NAAS, Honored Worker of Agriculture of Ukraine

Tserenyuk O. M., Institute of Animal Science of the NAAS, Head of Department, Doctor of Agricultural Sci., Associate Professor

Shkavro N. M., Institute of Animal Science of NAAS, Scientific Secretary, Candidate of Agricultural Sci., Senior Researcher

Sheiko I. P., Scientific and Practical Center of the National Academy of Sciences of Belarus for animal husbandry, first deputy Director General, Doctor of Agricultural Sci., Professor, Academician of NAS of Belarus, Honored Worker of Sci. of the Republic of Belarus (Republic of Belarus)

Eugeniusz Herbut, Instytut Zootechniki PIB, Dzial Technologii, Ecology and Economics Produkcji Zwierzqcej, Doctor habilitowany, Professor (Republic of Poland)

Waldemar Korol, Instytut Zootechniki PIB, Kierownik Krajowego Laboratoryium Pasz w Lublinie, Doctor habilitowany (Republic of Poland)

It is recommended for printing by the decision of the Scientific Council of the Institute of Animal Science of the NAAS (protocol No. 14 of November 12, 2019).

The Bulletin is included in the new list of scientific publications of Ukraine, international scientific databases Russian Index of Scientific Citation - (RINC) (license agreement № 649-10 / 2013 of October 23, 2013) and Google Scholar.

The electronic version is available on the portal of the Vernadsky National Library of Ukraine and on the website of the Bulletin on the website of the founder http://animal.kharkov.ua/index.php/cainspublication/ntb

Individual institution prefix in Crossref 10.32900. The scientific content of the journal is assigned an international DigitalOobjecti Index (DOI).

ISSN 2312-8402 